\section{Decreased Expression of Human Class II Antigens on Monocytes from Patients with Acquired Immune Deficiency Syndrome Increased Expression with Interferon- $\gamma$}

\author{
Wyrta Heagy, Vicki E. Kelley, Terry B. Strom, \\ Kenneth Mayer, Howard M. Shapiro, Richard Mandel, \\ and Robert Finberg \\ Dana-Farber Cancer Institute, Laboratory of Infectious Diseases \\ and Departments of Medicine and Pathology, Harvard Medical \\ School; Brigham and Women's Hospital and Harvard Medical \\ School, Department of Medicine; Laboratory of Immunogenetics \\ and Transplantation, Beth Israel Hospital, Boston, Massachusetts \\ 02115; Brown University, Department of Medicine, Providence, \\ Rhode Island 02912; Fenway Health Care Center; and Center for \\ Blood Research, Boston, Massachusetts 02115
}

\section{Introduction}

II histocompatibility antigen) on monocytes isolated from the peripheral blood of normal individuals and patients with acquired immune deficiency syndrome (AIDS) was investigated by the use of dual fluorescent staining and cytofluorometry. In animal models the absence of class II positive monocytes is linked to a failure of $\mathrm{T}$ cells to respond to antigens.

We now report that patients with AIDS have a paucity of HLA-DR ${ }^{+}$monocytes. The percentage of $\mathrm{HLA}-\mathrm{DR}^{+}$monocytes among eight normal individuals ranged from 49.3 to $95.0 \%+$, and only one individual had $<50 \%$ HLA-DR ${ }^{+}$monocytes. HLA-DR expression on monocytes from homosexual male patients with lymphadenopathy was similar to that of normal subjects (range, 58.0 to $97.4 \%+$ ). In contrast, seven of nine patients with AIDS had $<50 \% \mathrm{HLA}^{-D^{+}}$monocytes (range, 13.4 to $78.8 \%+$ ). The in vitro incubation of monocytes from AIDS patients with cloned human interferon- $\gamma$ resulted in an increase of the expression of HLA-DR to near normal levels.

Address reprint requests to Dr. Heagy, Laboratory of Infectious Diseases, Dana-Farber Cancer Institute, 44 Binney Street, Boston, MA 02115. Received for publication 19 March 1984 and in revised form 15 June 1984

J. Clin. Invest.

(C) The American Society for Clinical Investigation, Inc. 0021-9738/84/12/2089/08 \$1.00

Volume 74, December 1984, 2089-2096
Acquired immunodeficiency syndrome (AIDS) ${ }^{1}$ is a recently described, lethal disease characterized by quantitative, as well as qualitative, abnormalities in subpopulations of $\mathrm{T}$ lymphocytes, and by infections not seen in normal hosts including infection with Pneumocystis carinii, disseminated toxoplasmosis, and cytomegalovirus (CMV) infection (1-8). The high incidence of neoplasm, especially Kaposi's sarcoma (3-4), may reflect an inadequate immune response to oncogenic viruses. Patients with AIDS are subject to infection with Herpes group viruses. Disseminated viral infections with herpes simplex, varicella zoster, and CMV are common (7-8), and human T cell leukemia virus has been identified in some patients (9-12).

Patients with AIDS have $\mathrm{T}$ lymphocyte abnormalities including: (a) a reduced percentage of $\mathrm{T}^{+}$cells in the peripheral blood; $(b)$ inverted ratios of $\mathrm{T}^{+} / \mathrm{T}^{+}$cells; and $(c)$ defective cellular immune functions $(1-6,13)$. In vitro $T$ lymphocyte responses to specific antigens and mitogens are reduced and natural killer cell activity is decreased $(6,14)$. The factors underlying these abnormalities are not understood.

HLA-DR, a class II human major histocompatibility complex (MHC) antigen (homologous to mouse Ia), is a glycoprotein expressed on B lymphocytes and certain immune cells serving an accessory (antigen-presenting) role within the immune system, but not on other cells (15-19). Recently, gammainterferon (IFN- $\gamma$ ) has been shown to induce expression of

1. Abbreviations used in this paper: AIDS, acquired immune deficiency syndrome; CHO, Chinese hamster ovary; CMV, cytomegalovirus; FITC, fluorescein isothiocyanate; IFN- $\gamma$, gamma-interferon; IL-2, interleukin-2; MHC, major histocompatibility complex. 
HLA-DR upon blood monocytes, human fetal monocytes, several myeloid leukemic cell lines, and endothelial cells (20-22).

In both humans and mice, the ability of $\mathrm{T}$ cells to respond to antigen is totally dependent upon interaction with class II MHC positive accessory cells (23-27). In the absence of such class II positive accessory cells, $\mathrm{T}$ cells fail to respond to viruses or nominal antigens; however, $\mathrm{T}$ cell function is restored by the addition of $\mathrm{Ia}^{+}$cells (27-28). Since the HLA-DR antigen is a marker for human Ia, the absence of HLA-DR ${ }^{+}$accessory cells could, in theory, cause a complete collapse in cellular immunity which would be reflected as a defect in the ability of $T$ cells to respond to antigens. Consequently, we have examined HLA-DR on monocytes from patients with AIDS. Using a system that detects two-color fluorescence by cytofluorometry, we determined that monocytes harvested from the circulating blood of AIDS patients express reduced levels of HLA-DR.

The availability of recombinant DNA produced human IFN- $\gamma$ allows us to consider this as a therapeutic modality. Because IFN- $\gamma$, a product of activated $T$ cells, increases the expression of HLA-DR (20-22) we incubated monocytes obtained from patients with AIDS with cloned human IFN- $\gamma$. We found that in vitro treatment of monocytes obtained from AIDS patients with the cloned human IFN- $\gamma$ increased the expression of HLA-DR to near-normal levels.

\section{Methods}

Subjects. The patients studied were homosexual men or intravenous drug users diagnosed as having AIDS or lymphadenopathy. The diagnoses and laboratory findings for patients with AIDS are listed in Table I. All patients with AIDS had biopsy proven pneumocystis pneumonia and/or Kaposi's sarcoma. Patients with the lymphadenopathic syndrome were homosexual men with unexplained persistent lymphadenopathy ( $>3 \mathrm{mo}$ ) in two or more extrainguinal sites without obvious infection. At the time of study none was receiving interferon or steroids (or other agents known to affect $T$ cell function) except as noted (Table I).

Adherent cells. Mononuclear leukocytes were isolated under sterile conditions from $60-100 \mathrm{ml}$ of heparinized peripheral blood by FicollHypaque density gradient centrifugation. 30-ml aliquots of blood were layered over $15 \mathrm{ml}$ of lymphocyte separation medium (Litton Bionetics, Kensington, MD). After centrifugation, cells at the interface were collected, washed twice with M199 medium (MA Bioproducts, Walkersville, MD) supplemented with 5\% fetal bovine serum (FBS) (Sterile Systems, Inc., Logan, Utah), and $2 \mathrm{mM}$ glutamine and $100 \mathrm{U} / \mathrm{ml}$ penicillin-streptomycin (Gibco Laboratories Inc., Grand Island, NY). In initial studies cells were resuspended in M199 containing 20\% FBS, plated into two 60-mm culture dishes (Falcon Labware, Div. of BectonDickinson \& Co., Oxnard, CA), and incubated at $37^{\circ} \mathrm{C}$ in $5 \% \mathrm{CO} 2$ for $16 \mathrm{~h}$. In later studies cells were resuspended in RPMI 1640 (Gibco Laboratories Inc.) supplemented with 20\% FBS and plated in 8-ml volumes into $100-\mathrm{mm}$ dishes at densities of $15-25 \times 10^{6}$ cells/dish in order to increase the number of cells adhering to the tissue culture plates. To remove the nonadherent cells plates were washed twice with warmed L-15 medium (Gibco Laboratories, Inc.). RPMI 1640 supple- mented with $20 \%$ FBS was added to the adherent cells and incubations in $5 \% \mathrm{CO}_{2}, 37^{\circ} \mathrm{C}$, were continued for an additional $2 \mathrm{~d}$.

Adherent cells were obtained by washing twice with warmed $\left(37^{\circ} \mathrm{C}\right)$ $\mathrm{Ca}^{++} \mathrm{Mg}^{++}$-free Hanks' balanced salt solution (MA Bioproducts) and then incubating at $37^{\circ} \mathrm{C}$ for $10 \mathrm{~min}$ in $2.5-5 \mathrm{ml}$ of trypsin-versene mixture (200 mg versene and $500 \mathrm{mg}$ trypsin 1:250/liter in balanced salt solution; MA Bioproducts). The reaction was stopped by the addition of an equal volume of RPMI medium containing 20\% FBS. Finally, these cells were transferred to $15-\mathrm{ml}$ tubes and washed twice in RPMI medium.

Treatment with interferon. The human IFN- $\gamma$ used in these studies was obtained from a constitutively secreting cloned Chinese hamster ovary (CHO) cell line transfected with plasmid containing the human IFN- $\gamma$ gene (29). Control medium was derived from the same parent CHO line without the IFN- $\gamma$ gene and thus did not produce IFN- $\gamma$. Cloning and expression of IFN- $\gamma$ have been previously reported (29, 30). Adherent cells isolated from peripheral blood were incubated with the human IFN- $\gamma$ as previously described for fetal monocytes (21). Cells were incubated in $5 \% \mathrm{CO}^{2}$ at $37^{\circ} \mathrm{C}$ for $2 \mathrm{~d}$ in control medium or medium containing $50 \mathrm{U} / \mathrm{ml}$ of IFN- $\gamma$.

Antibody staining. In the course of the present study, we used several anti-human mouse monoclonal antibodies: LB3.1 (IgG 2b), which defines a haplotype shared (framework) HLA-DR determinant (21) (a gift of Drs. Peter Knudsen and Jack Strominger, Dana-Farber Cancer Institute); fluorescein isothiocyanate (FITC)-conjugated MO2 (IgM), a marker specific for adherent monocytes (31) (Coulter Immunology, Hialeah, FL); OKT4 (IgG2b), a marker for helper T cells (Ortho Diagnostics, Raritan, NJ); anti-Leu-1 phycoerythrin conjugate, a marker for $\mathrm{T}$ cells (Becton-Dickinson \& Co., Mountain View, CA), and FITC-conjugated $\mathrm{J} 13$ (IgM), an antibody recognizing the human common acute lymphoblastic leukemia antigen (a gift of Dr. Robert Todd, Dana-Farber Cancer Institute).

Indirect cell staining of monoclonal antibodies was conducted by use of a sheep $F\left(a b^{\prime}\right)_{2}$ anti-mouse Ig-Texas red (New England Nuclear, Boston, MA) or goat $\mathrm{F}\left(\mathrm{ab}^{\prime}\right)_{2}$ anti-mouse Ig-FITC (Meloy Laboratories Inc., Springfield, VA).

In studies not using double labeling (see below) adherent cells were treated twice with a 1:10 dilution of OKT3 (32) (Ortho Diagnostics) for $30 \mathrm{~min}$ at $20^{\circ} \mathrm{C}$ followed by a 30 -min incubation at $37^{\circ} \mathrm{C}$ in rabbit complement (Pel-Freeze Biologicals Rogers, AR).

In order to block nonspecific antibody binding by cellular Fc receptors, cells were preincubated in $1 \mathrm{ml}$ of $50 \%$ AB human serum in phosphate-buffered saline (PBS) before antibody staining. For twocolor fluorescence analysis (33) (double labeling) $1 \times 10^{5}$ to $1 \times 10^{6}$ cells were first incubated with 100-200 $\mu$ l of LB3.1 (1:50 dilution of ascites) followed by three washes in 2-ml portions of PBS containing $1 \%$ FBS. The LB3.1 antibody was then labeled by incubation of cells with $25-50 \mu l$ of a 1:10 dilution of sheep $\mathrm{F}\left(\mathrm{ab}^{\prime}\right)_{2}$ anti-mouse Ig-Texas red. After three washes (as above) cells were incubated with 200-300 $\mu \mathrm{l}$ of reconstituted FITC-conjugated MO2. Subsequently, cells were washed (three times), fixed in $2 \%$ formalin, and stored in the dark at $1^{\circ} \mathrm{C}$.

Antibody staining of surface antigens was quantitatively analyzed with flow cytofluorometry on a Becton-Dickinson Dual Laser FACS 440 equipped with a Consort 40 data management system (BectonDickinson \& Co.).

Statistical analysis. Statistical analysis of data was performed at the Core Lab Computer Facilities of Beth Israel Hospital, Boston. A $t$ test was used to analyze the percentage monocytes expressing HLADR from normal individuals and patients with AIDS. A two-factor 
Table I. Profile of Patients With AIDS

\begin{tabular}{|c|c|c|c|c|c|c|c|}
\hline Patients & Age & Risk group & WBC & $\% \mathrm{~L}$ & \%M & $\begin{array}{l}\text { Helper/suppressor } \\
\text { (T4/T8 ratio) }\end{array}$ & Diagnosis \\
\hline & $y r$ & & & & & & \\
\hline 1 & 39 & Homosexual & 3.2 & 12 & 6 & 0.15 & $\begin{array}{l}\text { Pneumocystis pneumonia } \\
\text { Disseminated CMV }\end{array}$ \\
\hline 2 & 38 & Homosexual & 8.5 & 9 & 5 & 0.15 & $\begin{array}{l}\text { Pneumocystis pneumonia } \\
\text { Mycobacterium avian } \\
\text { intracellulare }\end{array}$ \\
\hline 3 & 34 & Homosexual & 3.2 & 6 & 7 & 0.20 & $\begin{array}{l}\text { Kaposi's sarcoma } \\
\text { Cryptosporidiosis }\end{array}$ \\
\hline 4 & 35 & Bisexual & 2.1 & 2 & 4 & 0.10 & $\begin{array}{l}\text { Pneumocystis pneumonia } \\
\text { (two times) } \\
\text { Mycobacterium avian } \\
\text { intracellulare }\end{array}$ \\
\hline 5 & 34 & Intravenous drug & 2.4 & 10 & 5 & 0.14 & $\begin{array}{l}\text { Pneumocystis pneumonia } \\
\text { Disseminated CMV } \\
\text { Mycobacterium avian } \\
\text { intracellulare }\end{array}$ \\
\hline 6 & 38 & $\begin{array}{l}\text { Intravenous drug } \\
\text { Homosexual }\end{array}$ & 2.9 & 30 & 7 & 0.31 & $\begin{array}{l}\text { Pneumocystis pneumonia } \\
\text { Disseminated CMV and } \\
\text { HSV }\end{array}$ \\
\hline $7^{*}$ & 26 & Homosexual & 12.8 & 12 & 10 & 0.20 & $\begin{array}{l}\text { Pneumocystis pneumonia } \\
\text { Recurrent candidiasis } \\
\text { Recurrent genital herpes } \\
\text { CNS toxoplasmosis } \\
\text { Kaposi's sarcoma }\end{array}$ \\
\hline 8 & 42 & Homosexual & 5.9 & 60 & 7 & 0.22 & $\begin{array}{l}\text { Kaposi's sarcoma } \\
\text { Pneumocystis pneumonia }\end{array}$ \\
\hline 9 & 45 & Homosexual & 3.6 & 23 & 9 & 0.14 & $\begin{array}{l}\text { Kaposi's sarcoma } \\
\text { Cryptosporidiosis }\end{array}$ \\
\hline
\end{tabular}

CNS, central nervous system. WBC, white blood cells. L, lymphocytes. M, monocytes. * At the time of our studies was receiving steroid therapy for CNS toxoplasmosis.

analysis of variance adjusted for unequal sample size was used to analyze control and IFN- $\gamma$ treated cells.

\section{Results}

Measuring HLA-DR expression on monocytes. Initially we employed indirect staining of adherent cells with single antibodies and goat $F\left(a b^{\prime}\right)_{2}$ anti-mouse FITC. Before antibody staining was done, the cells were treated with OKT3 and complement in order to remove $\mathrm{T}$ cells. In the case of patients with AIDS, cell recovery was so low that it was difficult to recover enough cells to establish cell surface phenotypes with a panel of antibodies.
Because of the low cell recovery and because HLA-DR is present on both B cells and monocytes, we analyzed HLA-DR expression by indirect (two-antibody) labeling of LB3.1 (antiHLA-DR) with Texas red fluorescent dye, whereas monocytes were identified by the use of FITC-conjugated MO2 antibody (MO2-FITC). We could simultaneously analyze, therefore, both cell surface markers and ascertain the percentage of monocytes expressing surface HLA-DR. This technique allowed us to quantitate HLA-DR expression on monocytes by analyzing only those cells that stained with the MO2 antibody.

The data presented in Table II were generated through study of adherent mononuclear cells obtained from a normal individual; the data demonstrate that the double staining 
Table II. Two-Color Fluorescence Analysis of the Adherent Cells From Normal Peripheral Blood*

\begin{tabular}{|c|c|c|c|c|c|c|c|c|}
\hline \multicolumn{2}{|l|}{ Red staining } & \multirow{3}{*}{$\begin{array}{l}\begin{array}{l}\text { Green } \\
\text { staining }\end{array} \\
\text { FITC-MO2 }\end{array}$} & \multirow{2}{*}{\multicolumn{5}{|c|}{ Percentage of cells staining $\ddagger$}} & \multirow{3}{*}{$\begin{array}{l}\text { Percentage } \\
\text { HLA-DR } \\
\text { within the } \\
\text { total MO2 } \\
\text { population }\end{array}$} \\
\hline \multirow{2}{*}{$\begin{array}{l}\text { First antibody } \\
\text { LB3.1 } \\
\text { (Anti-DR) }\end{array}$} & \multirow{2}{*}{$\begin{array}{l}\text { Second antibody } \\
\text { Texas red } \\
\text { (sheep anti-mouse } \operatorname{lgG} \text { ) }\end{array}$} & & & & & & & \\
\hline & & & $\begin{array}{l}\text { HLA-DR- } \\
\mathrm{MO2}^{-}\end{array}$ & $\begin{array}{l}\text { HLA-DR }{ }^{+} \\
\text {MO2- }^{-}\end{array}$ & $\begin{array}{l}\text { HLA-DR- } \\
\mathrm{MO}^{+}\end{array}$ & $\begin{array}{l}\text { HLA-DR }{ }^{+} \\
\mathrm{MO2}^{+}\end{array}$ & $\begin{array}{l}\text { Total } \\
\mathrm{MO2}^{+}\end{array}$ & \\
\hline+ & - & + & 6.1 & 0.0 & 92.7 & 0.0 & 92.7 & - \\
\hline+ & + & - & 27.8 & 77.0 & 0.1 & 0.6 & 0.7 & - \\
\hline+ & + & + & 5.3 & 4.0 & 24.0 & $68.6 \S$ & 92.6 & 74.1 \\
\hline- & + & - & 98.8 & 1.4 & 0.4 & $0.2 \S$ & 0.6 & 一 \\
\hline
\end{tabular}

* Normal cells were prepared from the buffy coat cells of a normal donor. $¥$ In order to assess nonspecific staining, adherent cells were stained with OKT4 (like LB3.1, an IgG2b antibody), a helper T cell specific antibody. Staining of the adherent cell population by OKT4 ranged from 1.8 to $6.5 \%$. § Percentages calculated from the analysis of 20,000 cells. In some cases summation of percentage values for all cell groups exceeded $100 \%$. This occurred in the two-color analysis when cells fell on the border lines of windows used in defining negative, red, and green fluorescence. In these cases cells were counted twice resulting in values $0.8-1.9 \%>100$.

technique can indeed facilitate study of HLA-DR upon $\mathrm{MO2}^{+}$ cells. Staining with MO2-FITC resulted in $92.7 \% \mathrm{MO}^{+}$cells; staining with LB3.1/Texas red resulted in $77.0 \%$ HLA-DR $^{+}$ cells. Double staining for both determinants showed $68.6 \%$ $\mathrm{HLA}^{-\mathrm{DR}^{+} / \mathrm{MO}^{+}, 4 \% \text { HLA-DR }}{ }^{+} / \mathrm{MO}^{-}, 24 \% \mathrm{HLA}^{-} \mathrm{DR}^{-}$/ $\mathrm{MO}^{+}$, and 5.3\% HLA DR ${ }^{-} / \mathrm{MO}^{-}$cells. Among the doubly stained cells, $92.6 \%(68.6+24.0)$ were $\mathrm{MO}^{+}, 72.6 \%(68.6$ $+4.0)$ were HLA-DR ${ }^{+}$, and the percentage HLA-DR ${ }^{+}$cells within the total $\mathrm{MO}^{+}$population was $74.1 \%$. Background staining with Texas red in the absence of LB3.1 resulted in $1.6 \%$ HLA-DR ${ }^{+}$cells. As nonspecific binding, especially through Fc-receptors, could be a problem in such an analysis we determined background staining with irrelevant antibodies. Substituting the subclass identical IgG2b T4 helper cell antibody for LB3.1 in the two-color staining protocol resulted in only $1-6 \%$ of the $\mathrm{MO}^{+}$cells staining red. Substitution of another IgM antibody (the anti-common acute lymphoblastic leukemia antigen, J13-FITC) for MO2-FITC resulted in 1-10\% of the adherent cells staining green. Hence, background staining, as determined with these nonmonocyte specific antibodies, was $<10 \%$.

HLA-DR expression in patients with AIDS. Our initial studies using indirect staining of cells with single antibodies showed HLA-DR expressed on $81-94 \%$ of adherent cells from four normal individuals. These data are in agreement with previously reported studies that cite values ranging between 75 and $90 \%(34,35)$. In one patient with AIDS with enough cells for quantitation it was determined that only $17 \%$ of the adherent cells were HLA-DR ${ }^{+}$. In three other patients with AIDS the adherent cell population contained markedly fewer HLA-DR positive cells than in normal subjects.

To determine if the cells examined were monocytes and not contaminating B or T cells, and to allow us to use multiple stains on a small number of cells, we then used dual labeling techniques. All subsequent results were expressed in terms of the percentage of $\mathrm{HLA}-\mathrm{DR}^{+}$cells among the $\mathrm{MO}^{+}$population
(Table II). The data derived from double staining of HLA-DR and MO2 on cells from eight normal individuals, four patients with lymphadenopathy, and six patients with AIDS is shown in Fig. 1.

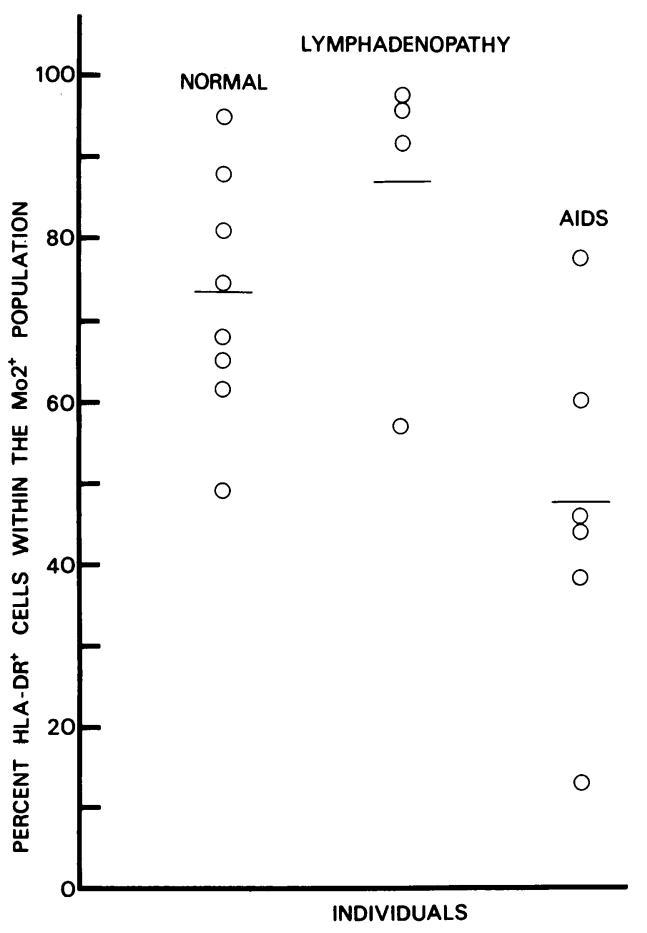

Figure 1. Percentage HLA-DR ${ }^{+}$monocytes isolated from peripheral blood of normal individuals and patients with lymphadenopathy and AIDS. Open circles show the percentages obtained for individuals, and cross bars show the mean of each group. The difference in percentage HLA-DR ${ }^{+}$monocytes between normal subjects and patients with AIDS was significant $(t$ test; $P<0.01)$. 
Analysis of the normal individuals was performed on cells from six men and two women. For women the percentage of monocytes expressing HLA-DR was 88.0 and $61.4 \%$. For normal individuals (Fig. 1) the mean \pm SD for the percentage of monocytes expressing HLA-DR was $72.9 \pm 15.1 \%$. The range of these values was between 49.3 and $95.0 \%+$; only one individual had $<50 \%$ HLA-DR ${ }^{+}$monocytes $(49.3 \%+)$. Upon repeat analysis this individual showed $65.3 \% \mathrm{HLA}^{-\mathrm{DR}^{+}}$monocytes. In general, repeat analysis of other normal individuals showed modest variability. For example, in two different assays one individual had 95 and $83 \%$ HLA-DR ${ }^{+}$monocytes, and another showed 65 and $79 \%+$.

HLA-DR expression on monocytes from four patients with lymphadenopathy were similar to or higher than those for normal subjects, with a range of HLA-DR ${ }^{+}$monocytes between 58 to $97.4 \%$, and mean \pm SD of $86.2 \pm 18.9 \%$ (Fig. 1). Three of these four analyzed patients had $>90 \%$ HLA-DR ${ }^{+}$monocytes.

Of the six patients with AIDS, four had $<50 \%$ HLA-DR ${ }^{+}$ monocytes (Fig. 1). The values had a range between 13.4 and $78.8 \%+$ and a mean \pm SD of $46.2 \pm 22.0 \%$. It was possible to repeat the analysis on only one of these patients; this patient initially had $43 \%$ HLA-DR ${ }^{+}$monocytes and upon repeat, $24 \%$.

As previously reported by Nunez and Stastny (34) we found that there was little change in HLA-DR expression on monocytes with up to $4 \mathrm{~d}$ of in vitro culture. After a 2-h adherence, the percentage of HLA-DR ${ }^{+}$monocytes from three normal individuals was 75.3, 79.0, and 71.5. After $4 \mathrm{~d}$ in culture $61.4,61.4$, and $65.3 \%$, respectively, of the cells expressed HLA-DR.

Sztein et al. (36) have reported, however, that monocyte cultures thoroughly depleted of nonadherent cells showed progressively decreased HLA-DR expression over 2-5 d of incubation. During the in vitro incubation nonadherent contaminating $T$ cells may produce sufficient levels of IFN- $\gamma$ for maintaining HLA-DR expression. We therefore investigated the $T$ cell contamination of our monocyte cultures. The percentage of $T$ cells present within the cultures was determined by cytofluorometry after staining with the phycoerythrin conjugate of the pan $\mathrm{T}$ cell-marker anti-Leu-1. For two normal individuals the percentages of cells found to be Leu- $1^{+}$were 4.3 and 8.1 . For a patient with AIDS $0.59 \%$ of the cells stained with the anti-Leu-1 antibody.

To determine if the differences in HLA-DR expression observed in patients with AIDS and normal individuals resulted from a difference in contaminating $T$ cells present within the adherent cell cultures we measured HLA-DR on $\mathrm{MO}^{+}$cells within the mononuclear leukocyte population without either adhering or culturing of the cells. For normal individuals the percentage of monocytes expressing HLA-DR was 76.5, 52.2, and 79.4. For two patients with lymphadenopathy 48.6 and $82.9 \%$ of the monocytes were HLA-DR ${ }^{+}$. In contrast, two patients with AIDS had 19.7 and $37.7 \%$ HLA-DR $^{+}$monocytes. These results are similar to our findings with adherent cells after $4 \mathrm{~d}$ of in vitro culture. Hence, these data suggest that the observed decrease in HLA-DR on monocytes from patients with AIDS does not result from in vitro culturing or from differences in $\mathrm{T}$ cells contaminating the cultures.

In addition, Belsito et al. (37) have recently shown, using specimens from skin biopsies, that patients with AIDS have a reduced expression of human Ia on Langerhans cells, the antigen-presenting cells of the skin. The number of Langerhans cells that expressed human Ia was $\sim 37.0 \%$ that of the normal control group.

The observed decreases in human Ia expression on Langerhans cells and peripheral blood monocytes, two different populations of antigen presenting cells, therefore, supports the idea that we are measuring a defect that occurs in vivo as part of the immune deficiency syndrome of AIDS.

In vitro effect of IFN- $\gamma$ on $H L A-D R$ expression. Because of previous work indicating that IFN- $\gamma$ was able to increase expression of class II antigens on monocytes (20-22), we treated monocytes with recombinant DNA-produced IFN- $\gamma$ or a control supernatant for $48 \mathrm{~h}$ in vitro. A comparison of the IFN- $\gamma$ treated with control treated cells shows that IFN- $\gamma$ increased the percentage of $\mathrm{MO}^{+}$cells expressing HLA-DR (Table III). In the case of patients with AIDS, where HLA-DR expression was low, treatment with IFN- $\gamma$ caused an increase in HLA-DR to near-normal levels (Table III). The average for

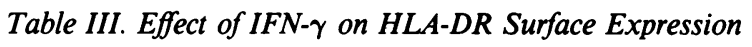

\begin{tabular}{|c|c|c|c|c|}
\hline \multirow[b]{2}{*}{ Treatment } & \multicolumn{2}{|c|}{ Percentage cells staining } & \multirow[b]{2}{*}{$\begin{array}{l}\text { Total } \\
\text { MO2 }^{+}\end{array}$} & \multirow{2}{*}{$\begin{array}{l}\text { Percentage* } \\
\text { HLA-DR } \\
\text { within the } \\
\text { total } \mathrm{MO}^{+} \\
\text {population }\end{array}$} \\
\hline & $\begin{array}{l}\text { HLA-DR }^{+} \\
\mathrm{MO2}^{+}\end{array}$ & $\begin{array}{l}\text { HLA-DR- } \\
\text { MO2 }^{+}\end{array}$ & & \\
\hline \multicolumn{5}{|l|}{ AIDS } \\
\hline Medium & 29.0 & 38.5 & 67.5 & 43.0 \\
\hline IFN- $\gamma$ & 66.0 & 5.0 & 71.0 & 93.0 \\
\hline Medium & 8.8 & 56.9 & 65.7 & 13.4 \\
\hline IFN- $\gamma$ & 72.3 & 25.0 & 97.3 & 74.3 \\
\hline Medium & 23.6 & 30.7 & 54.3 & 43.5 \\
\hline IFN- $\gamma$ & 44.3 & 10.6 & 54.9 & 80.7 \\
\hline \multicolumn{5}{|c|}{ Normal subjects } \\
\hline Medium & 60.6 & 8.3 & 68.3 & 88.7 \\
\hline IFN- $\gamma$ & 73.1 & 15.5 & 77.6 & 94.2 \\
\hline Medium & 73.8 & 15.5 & 89.3 & 82.6 \\
\hline IFN- $\gamma$ & 89.9 & 2.0 & 91.9 & 97.8 \\
\hline Medium & 80.0 & 4.2 & 84.2 & 95.0 \\
\hline IFN- $\boldsymbol{\gamma}$ & 92.0 & 6.4 & 98.4 & 93.5 \\
\hline Medium & 44.8 & 24.1 & 68.9 & 65.0 \\
\hline IFN- $\gamma$ & 59.4 & 2.0 & 61.4 & 96.7 \\
\hline Medium & 40.4 & 41.6 & 82.0 & 49.3 \\
\hline IFN- $\boldsymbol{\gamma}$ & 54.4 & 13.1 & 55.5 & 98.0 \\
\hline
\end{tabular}

- Analysis of variance (two factor adjusted for unequal sample size) showed the difference between AIDS and normal subjects was significant $(P=0.0017)$, as was the difference between IFN- $\gamma$ and medium treated $(P=0.0013)$ for AIDS and normal subjects. 
IFN- $\gamma$ treated HLA-DR ${ }^{+}$monocytes of patients was $82.7 \pm 9.5 \%$, in comparison with $33.3 \% \pm 17.2 \%$ HLA-DR ${ }^{+}$monocytes for the medium control (Table III).

As previously reported we found that IFN- $\gamma$ also increased HLA-DR expression on normal cells (20-22). With the exception of one individual who showed $95 \%$ HLA-DR ${ }^{+}$monocytes in the absence of IFN- $\gamma$, IFN- $\gamma$ increased HLA-DR expression with all other normal individuals (Table III). With normal subjects the average percentage of cells staining HLA-DR ${ }^{+}$in the IFN- $\gamma$ treated group was $96.0 \pm 2.1+$ as compared with $76.1 \pm 18.7+$ for monocytes maintained in the medium controls.

Most experiments were performed comparing the supernatant from the $\mathrm{CHO}$ line with the IFN- $\gamma$-containing plasmid with the supernatant from the non-plasmid-containing $\mathrm{CHO}$ line. Incubating adherent cells in cloned IFN- $\gamma$ that had been further purified $(>90 \%)$ resulted in similar increases in the expression of HLA-DR. Identical results were obtained using $E$. coli-produced human IFN- $\gamma$ (obtained from Biogen Research Corp., Cambridge, MA).

\section{Discussion}

We have analyzed the HLA-DR expression on monocytes from normal individuals, homosexual males with lymphadenopathy, and patients with AIDS. The range of HLA-DR ${ }^{+}$ monocytes was 49.3 to $95 \%$ for normal individuals, 58 to $\mathbf{9 7 . 4 \%}$ for patients with lymphadenopathy, and 13.4 to $78.8 \%$ for patients with AIDS (Fig. 1). The patients with AIDS are the first group of patients shown to have a deficiency in HLADR expression on monocytes. It is interesting that the incubation of AIDS monocytes with IFN- $\gamma$ resulted in an increase in the percentage of monocytes expressing HLA-DR to values approaching those of normal individuals (74.3 to $93 \%+$ ). At present, we do not know why some patients with AIDS show decreased HLA-DR and others fall within the normal range. We have examined only a small number of patients; thus, further studies are necessary to determine the percentage of patients who show decreased HLA-DR and to correlate this defect with other factors in AIDS.

Currently, therapeutic approaches to AIDS are attempting to correct the immunodeficiency by enhancing $T$ cell activity. The effects of both interleukin-1 (secreted by monocytes) and interleukin-2 (IL-2), a product of T cells, are under study. In vitro, the addition of IL-2 was shown to augment both cytolytic $T$ lymphocyte and natural killer cell responses in patients with AIDS (14).

Class II MHC molecules are prerequisite for antigenpresenting (accessory) cell function (23-27), and are instrumental in triggering the mixed lymphocyte (24) and graft-vs.host reactions (38). Three types of human Ia (class II MHC) molecules have been identified and biochemically characterized: DR, DS (or DC), and SB $(39,40)$. DR and SB molecules are structurally different but both show sequence homology with murine I-E molecules, whereas DS (DC) is homologous to mouse Ia $(39,40)$. Gonwa et al. (41) reported that a population of monocytes expressing both DR and DS (or DC) was more efficient in antigen presentation in autologous mixed lymphocyte reactions than were monocytes that expressed only the DR antigen. Whether the antigen responsible for the ability to interact with $T$ cells is HLA-DR or the concomitantly expressed DS (DC) has not been established. Although we made no attempt in these studies to measure DS (DC) expression, immune interferon (IFN- $\gamma$ ) induces expression of both DR and DS (DC) antigens $(20,21,42)$. Recent data indicate that IFN- $\gamma$ may increase DS (DC) expression even more than DR (42). Also, we have not specifically examined different adherent cell subpopulations. It is possible that $T$ cell function is affected by class II antigen expression on subpopulations of monocytes (41) or on dendritic cells (43).

In severe combined immunodeficiency of Arabian foals, a disease sharing features with severe combined immunodeficiency in children, elaboration, of IFN- $\gamma$ by $\mathrm{T}$ cells is defective (44). It has been suggested that the IFN- $\gamma$ defect may be responsible for the immunodeficiency. It is possible that a deficiency of class II positive monocytes, such as we found for patients with AIDS, and a resultant lack of $\mathrm{T}$ cell stimulation could eventually lead to a deficiency in secretion of IFN- $\gamma$.

A number of factors that regulate $\mathrm{T}$ cell immune responses, such as interferons and IL-2, are secreted by specific $\mathrm{T}$ cell subsets (45). In AIDS, secretion of such lymphokines may be greatly decreased. The production of IL-2 is defective in AIDS patients $(14,46)$ and it is noteworthy that IL-2 is the primary stimulus causing IFN- $\gamma$ release from immune $T$ cells (47-49). Murray et al. (50) have reported that the production of IFN$\gamma$ by mitogen-stimulated lymphocytes is also low in patients with AIDS. Hence, progressive $T$ cell dysfunction may cause an IL-2 secretory defect leading in turn to an eventual IFN- $\gamma$ secretory defect.

Thus, one explanation for our findings is that the deficiency in $T$ cell secretion of IFN- $\gamma$ results in decreased HLA-DR expression. A progressive defect in IL-2 release may culminate in a failure to elaborate IFN- $\gamma$. The IFN- $\gamma$ secretory defect may result in low levels of class II antigen expression, which would cause severely impaired $T$ cell responses to antigen. This scenario has the elements of a vicious circle. Hence, such a defect could be a major block in $T$ cell responses to antigens which leaves patients vulnerable to an array of opportunistic infections. We are currently studying patients within the groups at high risk for development of AIDS to determine the relationship of the defect in macrophage expression of HLADR to other cellular deficits observed in AIDS. In addition we are now exploring the effects of administration of recombinant DNA-produced IFN- $\gamma$ in AIDS patients. Further work will be necessary to determine if treatment (in vivo) with cloned IFN$\gamma$ will augment the $T$ cell responses of patients with AIDS.

\section{Acknowledgments}

We are indebted to the Core Lab Computer Facilities, Beth Israel Hospital, supported in part by grant RR-01032 from the General 
Clinical Research Centers Program of the Division of Research Resources, National Institutes of Health, for help with data analysis; Mr. Ed Luther, Brigham and Women's Hospital for operation of the FACS 440; Drs. R. Schooley and J. Groopman for providing patient materials; and Ms. Ann Marie Bynoe for excellent secretarial help.

This work was supported in part by National Institutes of Health grants AM 33929, AM 30105, CA19589, and CA34979. Robert Finberg is a Scholar of the Leukemia Society of America.

\section{References}

1. Gottlieb, M. S., R. Schroff, H. M. Schanker, J. D. Weisman, P. T. Fan, R. A. Wolf, and A. Saxon. 1981. Pneumocystis carinii pneumonia and mucosal candidiasis in previously healthy homosexual men: evidence of a new acquired cellular immunodeficiency. $N$. Engl. J. Med. 305:1425-1431.

2. Masur, H., M. A. Michelis, J. B. Greene, I. Onarato, H. W. Murray, and S. Cunningham-Rundles. 1981. An outbreak of community-acquired Pneumocystis carinii pneumonia. N. Engl. J. Med. 305:1431-1438.

3. Centers for Disease Control's Task Force on Acquired Immunodeficiency Syndrome. 1981. Kaposi's sarcoma and Pneumocystis pneumonia among homosexual men-New York City and California. Morbid. Mortal. Weekly Rep. 30:305-308.

4. Haverkos, H. W., and J. W. Curran. 1982. The current outbreak of kaposi's sarcoma and opportunistic infections. CA-Cancer J. Clin. 32:330-339.

5. Siegal, F. P., F. Lopez, G. S. Hammer, et al. 1981. Severe acquired immunodeficiency in male homosexuals manifested by chronic perianal ulcerative Herpes simplex lesions. N. Engl. J. Med. 305:14391444.

6. Mildvan, D., U. Mathur, R. W. Enlow, et al. 1982. Opportunistic infections and immune deficiency in homosexual men. Ann. Int. Med. 96:700-704.

7. Groopman, J. E., and M. S. Gottlieb. 1982. Kaposi's sarcoma: an oncologic looking glass. Nature (Lond.). 299:103-104.

8. Urmacher, C., P. Myskowski, M. Ochoa, M. Kris, and B. Safai. 1981. Outbreak of Kaposi's sarcoma with cytomegalovirus infection in young men. Ann. J. Med. 72:569-575.

9. Gallo, R. C., P. S. Sarin, E. P. Gelmann, et al. 1983. Isolation of human T-cell leukemia virus in acquired immune deficiency syndrome (AIDS). Science (Wash. DC). 220:863-865.

10. Barre'Sinoussi, F., J. C. Chermann, F. Rey, et al. 1983. Isolation of a $\mathrm{T}$ lymphotropic retrovirus from a patient at risk for acquired immune deficiency syndrome (AIDS). Science (Wash. DC). 220:868871.

11. Essex, M., M. F. McLane, T. H. Lee, L. Falk, C. W. S. Howe, and J. I. Mullins. 1983. Antibodies to cell membrane antigens associated with human $\mathrm{T}$ cell leukemia virus in patients with AIDS. Science (Wash. DC). 220:859-862.

12. Gellmann, E. P., M. Popovic, D. Blayney, H. Masur, et al. 1983. Proviral DNA of a retrovirus human T-cell leukemia virus, in two patients with AIDS. Science (Wash. DC). 220:862-864.

13. Kornfeld, H., R. A. V. Stouwe, M. Lange, M. Reddy, and M. Grieco. 1982. T lymphocyte subpopulation in homosexual men. $N$. Engl. J. Med. 307:729-731.

14. Rook, A. H., H. Masur, H. C. Lane, W. Frederick, T. Kasahara, A. M. Macher, J. Y. Djeu, J. F. Manischewitz, L. Jackson, A. S. Fauci, and G. V. Quinnan, Jr. 1983. Interleukin-2 enhances the depressed natural killer and cytomegalovirus-specific cytotoxic activities of lymphocytes from patients with the acquired immune deficiency syndrome. J. Clin. Invest. 72:398-403.
15. Strominger, J. L., V. H. Engelhard, and A. Fuks, et al. 1981. The biochemical analysis of products of MHC. In The Role of the Major Histocompatibility Complex in Immunobiology. M. E. Dorf, editor. Garland Press, New York. 115-172.

16. Bodmer, W. F. 1981. Structure and function: a contemporary view. Tissue Antigens. 17:9-20.

17. Schakelford, D. A., D. L. Mann, J. J. van Rood, G. B. Ferrara, and J. L. Strominger. 1981. Human B cell alloantigens DC1, MT1, and LB12 are identical to each other but distinct from the HLA-DR antigen. Proc. Natl. Acad. Sci. USA. 78:4566-4570.

18. Skaro, S., R. De Mars, S. F. Schlossman, P. L. Smith, L. A. Lampson, and L. M. Nadler. 1982. Serologic identification of the human secondary B cell antigens. Correlation between functions, genetics, and structure. J. Exp. Med. 156:731-743.

19. Hammerling, G. J. 1976. Tissue distribution of Ia antigens and their expression on lymphocyte subpopulations. 1976. Transplant Rev. 30:64-82.

20. Basham, T. Y., and T. C. Merigan. 1983. Recombinant interferon-gamma increases HLA-DR synthesis and expression. $J$. Immunol. 130:1492-1494.

21. Kelley, V. E., W. Fiers, and T. B. Strom. 1984. Cloned human interferon gamma, but not interferon beta or alpha, induces expression of HLA-DR determinants by fetal monocytes and myeloid leukemic cell lines. J. Immunol. 132:240-245.

22. Pober, J. S., M. A. Gimbrone, Jr., R. S. Cotran, C. S. Reiss, S. J. Burakoff, W. Fiers, and K. A. Ault. 1983. Ia expression by vascular endothelium is inducible by activated $\mathrm{T}$ cells and by human $\gamma$ interferon. J. Exp. Med. 157:1339-1353.

23. Benacerraf, B. 1981. Cellular interactions in the role of the major histocompatibility complex in immunology. In The Role of the Major Histocompatibility Complex in Immunobiology. M. E. Dorf, editor. Garland Press, New York. 255-269.

24. Termyijelen, A., A. van Leeuwen, and J. J. van Rood. 1982. HLA-linked lymphocyte activating determinants. Immunol. Rev. 66:79101.

25. Finberg, R., and B. Benacerraf. 1981. Induction, control and consequences of virus specific cytotoxic T cells. Immunol. Rev. 58:157180.

26. Dorf, M. E., and E. R. Unanue. 1978. Subpopulations of peritoneal macrophages identified with anti-Ia sera. In Ir Genes and Ia Antigens. H. O. McDevitt, editor. Academic Press, New York. 171174.

27. Yamashita, V., and E. M. Shevach. 1977. The expression of Ia antigens on immunocompetent cells in the guinea pig II. Ia antigens on macrophages. J. Immunol. 119:1584-1588.

28. Letvin, N. L., R. S. Kauffman, and R. Finberg. 1981. T lymphocytes immunity to reovirus: cellular requirements for generation and role in clearance of primary infections. J. Immunol. 127:23342339.

29. Devos, R., H. Cheroutre, Y. Faya, H. Degrave, H. Van Hevverswyn, and W. Fiers. 1982. Molecular cloning of human immune interferon cDNA and the expression in eukaryotic cells. Nucleic Acids Res. 10:2487-2501.

30. Scahill, S. J., R. Devos, J. Van der Heyden, and W. Fiers. 1983. Expression and characterization of the product of a human interferon cDNA gene in Chinese Hamster ovary cells. Proc. Natl. Acad. Sci. USA. 80:4654-4658.

31. Todd, R. F., L. M. Nadler, and S. F. Schlossman. 1981. Antigens on human monocytes identified by monoclonal antibodies. J. Immunol. 126:1435-1442.

32. Kung, P. C., G. Goldstein, E. L. Reinherz, and S. F. Schlossman. 
1979. Monoclonal antibodies defining distinctive human T cells surface antigens. Science (Wash. DC). 206:347-349.

33. Hardy, R. R., K. Hayakawa, J. Haaijman, and L. A. Herzenberg. 1982. B cells subpopulations identified by two-color fluorescence analysis. Nature (Lond.). 297:589-591.

34. Nunez, G., and P. Stastny. 1983. Cytofluorometric analysis of major histocompatibility antigens on human monocytes using monoclonal antibodies. Human Immunol. 6:1-11.

35. Sztein, M. B., P. S. Steeg, D. Mann, R. Stiehm, R. M. Blaese, and J. J. Oppenheim. Lymphokine induction of DR antigen expression on human neonatal and cell line monocytes. Cell Immunol. 70:389. (Abstr.)

36. Sztein, M. B., P. S. Steeg, H. M. Johnson, and J. J. Oppenheim. 1984. Regulation of human peripheral blood monocyte DR antigen expression in vitro by lymphokines and recombinant interferons. $J$. Clin. Invest. 73:556-565.

37. Belsito, D. V., M. R. Sanchez, R. L. Baer, F. Valentine, and G. J. Thorbecker. 1984. Reduced Langerhans cell Ia antigen and ATPase activity in patients with the acquired immunodeficiency syndrome. N. Engl. J. Med. 310:1279-1282.

38. Mason, D. W., M. Dallman, and A. N. Barclay. 1981. Graftversus-host disease induces expression of Ia antigen in rat epidemal cells and gut epithelium. Nature (Lond.). 293:150-151.

39. Bono, M. R., and J. L. Strominger. 1982. Direct evidence of homology between human DC-1 antigen and murine I-A molecules. Nature (Lond.). 299:836-838.

40. Hurley, C. K., S. Shaw, L. Nadler, S. Schlossman, and J. D. Capra. 1982. Alpha and beta chains of SB and DR antigen are structurally distinct. J. Exp. Med. 156:1557-1562.

41. Gonwa, T. A., L. J. Picker, H. V. Raff, S. M. Goyert, J. Silver, and J. D. Stobo. 1983. Antigen-presenting capabilities of human monocytes correlates with their expression of HLA-DS, an la determinant distinct from HLA-DR. J. Immunol. 130:706-711.
42. Ameglio, F., M. R. Capobianchi, A. Dolei, and R. Tosi. 1983. Differential effects of gamma interferon on expression of HLA Class II molecules controlled by the DR and DC Loci. Infect. Immun. 42:122-125.

43. Van Voorhis, W. C., R. M. Steinman, L. S. Hair, J. Luban, M. D. Witmer, S. Koide, and Z. Cohn. 1983. Specific antimononuclear phagocyte monoclonal antibodies. Application to the purification of dendritic cells and the tissue localization of macrophages. J. Exp. Med. 158:126-145.

44. Yilma, T., L. E. Perryman, and T. C. MoGuire. 1982. Deficiency of interferon-gamma but not interferon-beta in Arabian foals with severe immune deficiency. J. Immunol. 129:931-933.

45. O'Malley, J. A., S. D. Nussbaum-Blumenson, B. J. Grossmayer, and $H$. Ozer. 1982. Identification of the $T$ cell subset that produces human gamma interferon. J. Immunol. 128:2522-2526.

46. Sell, K. W., T. Folks, J. Kwon-chung, J. Coligan, and W. L. Meloy. 1983. Cyclosporin immunosuppression as the possible cause of AIDS. N. Engl. J. Med. 309.

47. Torres, B. A., W. Farrar, and H. M. Johnson. 1982. Interleukin 2 regulates immune interferon (IFN gamma) production by normal and suppressor cell cultures. J. Immunol. 128:2217-2219.

48. Kasahara, T., J. J. Hooks, S. F. Dougherty, and J. J. Oppenheim. 1983. Interleukin 2 mediated immune interferon (IFN-gamma) production by human $T$ cells and T cell subsets. J. Immunol. 130:17841789.

49. Kawase, I., C. G. Brooks, K. Kuribayashi, S. Olabuenaga, W. Newman, S. Gillis, and C. S. Henney. 1983. Interleukin 2 induces gamma-interferon production: participation of macrophages and NKlike cells. J. Immunol. 131:288-292.

50. Murray, H. W., B. Y. Rubin, H. Masur, and R. B. Roberts. 1984. Impaired production of lymphokines and immune (gamma) interferon in the acquired immunodeficiency syndrome. N. Engl. J. Med. 310:883-889. 